of class and individualism. Lorin Cary (University of Toledo) commented on oral history. And Mary Tyler (Southern California Library for Social Studies) detailed the development of a labor walking tour of Los Angeles.

Finally, the association continued its tradition of honoring for distinguished lifetime service to the labor movement an individual who has worked in or been associated with the location of the annual meeting. This year the award went to Delores Huerta of the United Farm Workers. John Fernandez, her brother, accepted the award on her behalf.

\title{
Organization of American Historians
}

\author{
Sarah Heath and Thomas Winter \\ University of Cincinnati
}

The panels on labor history at the 1991 OAH convention, held in Louisville in April 1991, offered a diverse range of topics. The sessions included "Video Production and Historical Interpretation: Commemorating a Century of Mine Workers' History," "Women, Work, and Family," "For Fun and Profit: Industrial Recreation in the Mid-Twentieth Century," "Labor and the State: The Exigency of Power," "The Politics of Labor in the Wilson Presidency," and "Records in the National Archives Relating to Twentieth-Century Protest and Dissent."

Several sessions gave evidence of the great interest in the topics of race, gender, and language among the profession. Several sessions addressed the history of Spanish-speaking peoples: "Working beyond Borders: Mexican Migrant Workers," and "Explorations in Chicano Labor History." On the panel "New Directions in Chicano and Filipino History," Jeffrey Garcilazo, speaking about "Mexican Railroad Workers in Kansas and the Southwest," argued that class and race determined the status of these workers and relegated them into being an industrial reserve army. Irene Ledesma, delivering a paper on "Gender and Labor Activism in Texas," argued that in the 1930s Mexican-American women began to transcend their passive, race and gender-determined role in the labor movement and created a public sphere of activism. Arlene deVera's paper on "McCarthyism and WestCoast Filipino Labor Organizing" illustrated how the courts and the INS used redbaiting to crush a local union by deporting the leaders.

At the session "The Politics of Exclusion and Working-Class Relations in the New South," Eric Arnesen, in his paper "Segmentation, Exclusion, and WorkingClass Race Relations in the New South," examined the Railroad Brotherhood's attempt to create a "Nordic closed shop." Arnesen argued that blacks' own racial consciousness served to mobilize a class awareness, which, in turn, functioned as a racially unifying factor. Dana Frank, talking about "Race, Class, and the Politics 
of Consumption: Race Relations in the Seattle Labor Movement, 1915-1929," claimed the almost total exclusion of African and Japanese-Americans forced these groups to organize on their own and eventually spurred a market system that actually facilitated the emergence of Japanese dominance in some sectors.

Two panels focused on the issue of language and labor. At the session, "The Languages of Labor," Michael Kazin, giving a paper on "Claiming the People for Labor: A Comparison of the Language of the AFL and the CIO, 1895-1950," argued that the AFL, and, eventually, the CIO, to organize labor and to justify their cause to the people, created a consensual creed for the purpose of conflict. Elizabeth Faue, speaking about "Brotherhood, Community, and the Citizen Soldier: Representations of Labor Solidarity," saw the AFL as pursuing both an inclusionist strategy of rhetorically linking citizenship to unionism, and an exclusionist approach in regard to gender and race. At the session "NineteenthCentury American Workers and the Rhetoric of Power," Gregory Kaster delivered his paper "Labor, the People and the Public, 1827-1877." Kaster maintained that labor's language was based on a post-millenial, republican producer ideology that often defied class terms in stressing the universal character of the labor movement. David Zonderman followed with "Uneasy Allies: Workers, Reformers and the New England Labor-Reform Leagues, 1840-1880." Zonderman examined how tensions between workers, who demanded stronger actions, and middle-class reformers, who limited their aspirations to debate and public advocacy of reform, led to the decline of both leagues.

This year's OAH offered a wide perspective on labor history. Unfortunately, the program committee had often scheduled several interesting panels at the same time. It is hoped this will be corrected in the future. 